\title{
Genetic characterization and diversity assessment in 'Bhangor' indigenous swamp buffalo population using heterologous microsatellite markers
}

Karan Veer Singh ( $\square$ karan.singh2@icar.gov.in )

ICAR-National Bureau of Animal Genetic Resources

\section{Ramendra Das}

Tripura Livestock Development Agency (TLDA), Animal Resources Development Department, Tripura.

\section{Ranjit Kataria}

ICAR-National Bureau of Animal Genetic Resources

Monika Sodhi

ICAR-National Bureau of Animal Genetic Resources

\section{Research Article}

Keywords: genetic diversity, microsatellite, molecular markers, Bhangor, SSR

Posted Date: May 13th, 2021

DOI: https://doi.org/10.21203/rs.3.rs-294166/v2

License: (c) (1) This work is licensed under a Creative Commons Attribution 4.0 International License. Read Full License 


\section{Abstract \\ Background}

The present study was aimed at genetic characterization and diversity analysis of indigenous swamp buffalo population 'Bhangor' from Tripura, India using the Food and Agriculture Organization (FAO) recommended bovine microsatellite markers. So far buffaloes of the northeastern states of India have been studied except for Tripura.

\section{Results}

Buffalo blood samples were collected from Tripura. Of the 24 microsatellite markers studied only 15 markers (CSSM33, BM1818, CSRM60, HEL13, ILSTS019, ILSTS025, ILSTS028, ILSTS029, ILSTS030, ILSTS033, ILSTS036, ILSTS056, ILSTS058, ILSTS061, ILSTS089 and ETH003) were found to be highly polymorphic in the population. A total of 114 alleles were secured, with an overall average of 7.60 alleles per locus. The number of alleles ranged from 3 (CSRM60 and ILSTS025) to 12 (ILSTS056 and ILSTS061). The mean effective number of alleles across all polymorphic loci was found to be 3.76. The overall mean expected heterozygosity and unbiased expected heterozygosity values were 0.67 and 0.68, ranging from 0.067 (ILSTS025) to 0.85 (ILSTS058) and 0.068 (ILSTS025) to 0.86 (ILSTS058), respectively. Within-population inbreeding estimates (FIS) for bhangor buffalo ranged between -0.4352 and 0.804 with an average FIS of $0.114 \pm 0.033$.

\section{Conclusions}

The outcome for IAM, TPM and test for mode shift revealed the absence of any recent bottleneck in Bhangor buffalo population. The population was found to be in optimum diversity based on polymorphic microsatellite markers. This is the newly characterized buffalo population from north-east India.

\section{Introduction}

India is one of the mega-diversity zones, with a rich diversity of buffaloes both riverine and swamp. It includes a total population of 108.7 million, animals that about $60 \%$ of the total buffalo population in the world. Most of which are riverine buffalo the elite milch breeds, contributing $50 \%$ to the national milk production of India. A total of 17 breeds of buffaloes are registered in India [1]. So far buffaloes of the north-eastern states of India have been studied except for Tripura and are generally considered as swamp type based on their phenotypic resemblance to swamp type buffaloes. The indigenous buffalo of Tripura are known as 'bhangor' or 'manipuri' by local people, as per the latest livestock census its population is approx 7000 [2].

These swamp buffaloes are reared mainly for draft power in the paddy fields and their population is declining. The present day mechanization of farmland operations and indiscriminate breeding practices threatens the genetic diversity in livestock populations. Moreover, with fast changing agroclimatic conditions, there is an urgent need to characterize the nondescript livestock populations at the molecular level. Genetic diversity analysis of livestock populations is important for breed identification, characterization, and studying population structure dynamics for conservation management. Molecular characterization and analysis of genetic diversity using microsatellite markers in different buffalo breeds in India [3-11] and world buffalo population [12-14] are available in the scientific literature. Microsatellites or simple sequence repeats (SSRs) are considered as markers of choice for the assessment of genetic diversity in livestock populations. In order to analyze and conserve withinand between-population genetic variability, Food and Agriculture Organization (FAO) has recommended a set of microsatellite markers for different livestock species (www.fao.org) [15].

The adult animals have typical swamp type characteristics; animals are generally gray or light-black in colour. The horn is curved like sickle with a broad base which is mostly corrugated. The horn tip pointed upward and backwards. The ears are horizontally placed. The forehead is mostly convex. Lower leg portion between hoofs and knee is of white to greyish-white in colour. The tail switch is generally black. The udder is bowl shaped and poorly developed, with small, cylindrical teats with pointed tips. The buffaloes have typical white markings on both sides of muzzle and lower jaw (Figs. 1 and 2). Animals had one white patch on the lower part of the neck region which is very prominent in young ones. Milking is not done thought milk yield varies between 1.5 to 2.5 liters per day. The fat percentage is high averaging about $8.5 \%$. The buffaloes are also used as source of meat protein, especially during traditional festivals. North-eastern part of India is the region where admixture of both riverine and swamp along with hybrids are present [16]. Recently indigenous swamp buffalo population in Meghalaya state of India has been characterised based on cytogenetic analysis [17].

The present study was undertaken to characterize and evaluate genetic diversity in the 'Bhangor' buffalo population from Tripura North-east India using FAO recommended microsatellite markers. Bhangor buffalo were characterized phenotypically and cytogenetically [18] however, 
characterisation in terms of genetic diversity was not studied yet. The genetic characterization of Bhangor buffalo gains significance for the maintenance of genetic diversity and prevention of germplasm erosion of indigenous livestock.

\section{Results}

A total of 15 microsatellite loci were found to be polymorphic and successfully amplified in Bhangor buffalo population. Locus wise allele frequency distribution and fragment sizes are presented in Fig. 3. A total of 114 alleles were recorded for 15 loci by genotyping 76 adult buffaloes, thus giving an average of $7.60 \pm 0.68$ alleles per locus. A maximum number of alleles were observed for ILSTS056 and ILSTS061 (12 alleles each) and minimum number of alleles for CSRM60 and ILSTS025 (3 alleles) as shown in other Indian riverine buffalo population [5, 19]. The mean effective number of alleles (Ne) across all polymorphic loci was found to be $3.76 \pm 0.39$. Ne ranged from 1.07 (ILSTS025) to 6.67 (ILSTS058).

The average estimate of expected heterozygosity $(\mathrm{He})$ was $0.67 \pm 0.05$ while unbiased estimate (Nei's He) was found to be $0.68 \pm 0.05$. The expected heterozygosity estimate was highest for ILSTS058 locus (0.85) and lowest for ILSTS025 (0.06). On the other hand, Nei's He estimate ranged from 0.068 (ILSTS025) to 0.86 (ILSTS058) in indigenous Bhangor population, as shown in other Indian riverine buffaloes population Murrah, Mehsana, Toda, Surti, Pandharpuri, Nilli Ravi, Tarai, Bhadawari, Jaffarabadi and Nagpuri buffaloes as revealed by [5, 20, 21].

Lowest Shannon's information index values were found to be 0.1740 (ILSTS025) and 0.725(CSRM60) in the local population, whereas the highest value was 2.054 (ILSTS061), total 8 loci were found having index value above 1.48 with an overall mean of $1.47 \pm 0.131$ thus showing higher gene diversity in the existing population.

The average PIC value indicates the informativeness of different microsatellite markers studied and also an important measure of DNA polymorphism. The average PIC was 0.63. In contrast, Acosta et al. (2014) obtained 0.495 PIC value for Cuban water buffalo [13] and Gullian buffaloes of Iran had 0.61 PIC values [22]. The PIC estimate ranged from 0.03 (ILSTS025) to 0.84 (ILSTS058) for studied loci. Table 2 depicts the details about the observed and expected number of alleles, heterozygosity (expected, observed and unbiased) and PIC values for each locus. Within-population inbreeding estimates (FIS) for Bhangor buffalo population ranged between -0.4352 and 0.804 with an average FIS of 0.114 $\pm 0.033$

In mutation drift equilibrium, heterozygosity excess/deficiency under the models generated by the BOTTLENECK is presented in Table no 3. Infinite allele model (IAM), and stepwise mutation model (SMM) under sign test showed deficiencies in 8 and 22 loci, respectively. Standardized difference and Wilcoxon test revealed significant heterozygosity excess under the Infinite allele model. The qualitative graphical method modeshift analysis revealed the normal L-shaped distribution of allele frequencies as depicted in Figure no 4, suggesting the absence of a recent genetic bottleneck in the Bhangor buffalo population. Table 4 summarizes the genetic distance estimate between Murrah, Nilli Ravi, Manda, Chilika, Kalahandi, Manipur and Assam, breeds based on uniform microsatellite data. The high genetic distance measure between the riverine populations supports a strong substructuring of the diversity. Gene flow among these populations was therefore low. However, a moderate genetic distance measure was observed with the Manipur and Assam populations (FST $=0.083,0.097 ; \mathrm{P}=0.072$ respectively), suggesting some gene flow between these populations ( $\mathrm{Nm}=1.127,1.568$ respectively).

\section{Discussion}

The present study is the first attempt toward the genetic characterization of Bhangor buffaloes using microsatellite markers. Sufficiently high allelic diversity was observed with a total number of 114 distinct microsatellite alleles across 15 loci. Tripura is landlocked state and its physiography is characterised by hills and valleys. Buffaloes are distributed in the hills as well as valley/plain regions of different parts of the state. The state has nine major rivers, over 400 wetlands, and swamps, providing a natural habitat for swamp buffaloes to wallow [23]. The total buffalo population of Tripura is estimated around 7000 (20th Livestock Census, 2019), 50\% of which is found in Unakoti district alone. Livestock in the state is mainly livelihood oriented and generally owned by small and marginal farmers. Population of the animal is decreasing over the years due to mechanisation of agriculture work and change in crop cultivation pattern. Destruction of natural grazing lands is one of the major concerns. The world famous indigenous Murrah buffalo has been brought in Tripura in the year 2013 for research and developmental purposes, to be explored for boosting milk production [24] and Al has been started in the border villages with tagged animals.

The observed number of alleles $(\mathrm{Na})$ and mean number of alleles are indicators of genetic variation in a population. The observed numbers of alleles $(\mathrm{Na})$ were higher than the effective numbers of alleles $(\mathrm{Ne})$ for all the loci studied. The mean observed numbers of alleles were found to be a little higher in the present study than that reported in Toda, Jaffarabadi (4.76), Bhadawari (4.7), Tarai (4.7), Chilika (4.68), Marathwada (4.48), Nagpuri, Pandharpuri and Banni buffaloes $[4,6,7,10,11,25,26,31]$ but is lower than the swamp population of Manipur and Nagaland

[16]. The higher number of allele secured implies increased allelic diversity present in the population. However 11 to 26 alleles per locus are also reported in Indian water buffalo [5]. These allelic differences may be attributed to the population under study, microsatellite markers studied, and the genetic polymorphism existing within the population itself. The mean effective number of alleles ( $\mathrm{Ne}$ ) across all polymorphic loci in 
Bhangor population was found to be $3.76 \pm 0.39$ where as in Assam and Manipur sample with same set of Loci it was $4.65 \pm 0.70$ and $4.30 \pm$ 0.39 respectively.

The average number of alleles obtained in the present study (7.60) was in line with FAO recommendation that suggests an analysis of at least 5 alleles per locus for genetic diversity based studies in livestock. Under the present study locus CSRM60 and ILSTS025 (3 alleles) all the markers demonstrated a good amount of polymorphism. Sukla et al. 2006 reported an average estimate of 5.5 alleles per locus for six Indian buffalo breeds based on 10 polymorphic microsatellite loci [27]. Similarly, an average of 5.15 alleles per locus was reported by Ozkan et al. in buffalo breed of Turkey [28] and with same set of loci Assam and Manipur sample showed 9.46 and 9.26 alleles per locus respectively. The effective number of alleles across all loci was lower than the observed values. The alleles with lower/rare frequency were considered as novel ones and these alleles may be assigned to population.

The average heterozygosity estimate of 0.670 was observed across all polymorphic loci for the population. The expected heterozygosity estimate was highest for ILSTS058 locus (0.85) and lowest for ILSTS025 (0.06). All the loci, except ILSTS025, exhibited high expected gene diversity, which are good measures to assess genetic diversity in a population. A similar average for Ho and He was observed in Colombian buffalo [12]. Substantially high average heterozygosity values pointed toward the existence of considerable genetic variability in the Bhangor buffalo population and suitability of the markers as well.

PIC value indicates an estimate associated with a particular marker for detecting polymorphism and it ranges from 0 to 1 . Markers with PIC value greater than 0.5 are considered important for genetic diversity based analysis [29]. Microsatellite loci ILSTS025 showed PIC estimate less than the threshold of 0.5 (Table 2) lower PIC values earlier reported in the Nagpuri Buffalo [30] and South Kanara buffalo [31] respectively and higher mean PIC value of 0.933 was reported in Egyptian buffalo [32], 0.73 in Pandharpuri buffalo [4], 0.73 in Mehsana buffalo [8] and 0.66 in Chilika buffalo [10]. The other markers were informative and important for genetic diversity and paternity based analysis in Bhangor population. Given the estimates of the observed and effective number of alleles, heterozygosity and PIC parameters, these marker loci may be used for carrying out the genetic studies on Bhangor population. Thus, the result suggests that there is substantial genetic variation and heterozygosity across the studied loci in Bhangor buffalo as assessed on the basis of 15 polymorphic microsatellite markers.

\section{Conclusion}

The analysis presented in this study provides the first preliminary data on the genetic diversity of the Bhangor non-descript swamp buffalo population from Tripura. Microsatellite markers used in the present study were highly polymorphic and revealed the effectiveness of studied markers in explaining the existing diversity levels, population structure and inbreeding status in the population. Bhangor buffaloes are distributed in a small area with less population size; various diversity indices suggest sufficient genetic variability in this population for its sustenance. These markers may be further used for breed characterization and to assist the conservation of genetic diversity of the Indian buffaloes.

\section{Material And Methods}

\section{Sample collection and genomic DNA isolation}

Habitat, distribution, management practices, utility, performance and socio-economic status of the farmers rearing 'Bhangor' buffalo was collected through preset questionnaires during the pilot survey conducted in Tripura state. A volume of $10 \mathrm{ml}$ blood sample was collected from 76 animals from several villages located in the remote area of the districts West Tripura, Khowai, Dhalai, Unakoti, Gomati, and North Tripura. Blood samples were collected under aseptic conditions through jugular vein puncture in sterile polypropylene tubes containing anticoagulant i.e., ethylene diamine tetra acetate (EDTA). Genomic DNA was isolated following standard phenol-chloroform extraction method [33]. The genomic DNA samples were evaluated for their purity, quality and concentration using agarose gel documentation and NanoDrop spectrophotometer (absorbance ratio 260/280nm).

\section{Selection of markers, PCR amplification and Microsatellite typing}

Bhangor buffaloes were genotyped using a battery 24 recommended microsatellite markers/loci (www.fao.org) present on the bovine genome. The information about these microsatellite markers along with corresponding primer sequences annealing temperature and chromosomal location are depicted in Table 1. $5^{`}$ end of forward primer of each microsatellite marker was labeled with one of the fluorescent dyes, viz., FAM (Blue), VIC (Green), NED (Yellow) or PET (Red) to assess the fragment length of genotyped PCR product with automated DNA sequencer (ABI 3100). However, only 15 microsatellite loci (CSSM33, BM1818, CSRM60, HEL13, ILSTS019, ILSTS025, ILSTS028, ILSTS029, ILSTS030, ILSTS033, ILSTS036, ILSTS056, ILSTS058, ILSTS061, ILSTS089 and ETH003) were found to be polymorphic for Bhangor population and hence were selected for studying genetic diversity. The markers used in this study were dinucleotide repeats which are more polymorphic than tri-nucleotides. The amplified products are clearly seen in the Agarose gel, and no non-specific amplification or PCR failure was observed. 
PCR amplification was carried out in thermal cycler in a final reaction volume of $15 \mu$ containing $10 \mathrm{pmol} / \mu \mathrm{l}$ of each primer, $10 \mathrm{mM}$ of each dNTP, 1.5mM MgCl2 and 1.2U Taq polymerase (Invitrogen, California), after optimization of annealing temperature for each microsatellite locus. After multiplexing of different dye-labeled amplified markers, the pooled samples were run on ABI automated DNA sequencer along with internal control LIZ standard. The data was extracted using GENEMAPPER software documenting the allele sizes for each marker in each animal [34].

\section{Statistical analysis}

The GenAlEx software (version 6.503) [35] was employed to calculate different within-population diversity measures viz, mean number of alleles per locus ( $\mathrm{Na}$ ), effective number of alleles per locus ( $\mathrm{Ne}$ ), observed heterozygosity (Ho) and coefficient of genetic diversity (He) of Nei for microsatellite loci analyzed in Bhangor buffaloes. Within-population-inbreeding estimates (FIS) were calculated using FSTAT computer program (version 2.9.3.2) [36]. Polymorphism information content (PIC) values were estimated through allele frequencies using the following equation: see equation 1 in the supplementary files.

Hardy-Weinberg equilibrium test was used to detect whether the present population has undergone any recent reduction in the effective population size or genetic bottleneck. Three different tests: sign test, standardized differences test and Wilcoxon sign-rank test under stepwise mutation model, the infinite allele model and the two-phase model of microsatellite evolution were used to compare the expected heterozygosity (HE) at Hardy-Weinberg equilibrium with the heterozygosity expected at mutation drift equilibrium (Heq). Bottleneck 1.2.01 software was used to conduct sign test, standardized differences test and Wilcoxon sign-rank test to detect whether buffalo population has undergone any recent reduction in the effective population size or genetic bottleneck [37]. For genetic relationship studies between Bhangor buffalo with established riverine Murrah, Nilliravi, Manda, Chilika, Kalahandi and swamp population of Manipur and Assam, microsatellite data generated from same set of loci in the Lab were used.

\section{Declarations}

\section{Ethics statement}

1. The study was approved by the ICAR-National Bureau of Animal Genetic Resources, Karnal. All methods were carried out in accordance with guidelines and regulations of the concerned committee. Morphometric data of the animals were collected based on preset questionnaires prepared by ICAR-NBAGR and informed consent was obtained from the farmers during the pilot survey conducted in Tripura state.

2. All methods were carried out in accordance with relevant guidelines and regulations of ICAR-NBAGR. Animal blood samples were collected by a trained veterinarian.

\section{Consent for publication}

All authors have given consent for publication. Institute ICAR-NBAGR, PME cell was informed about paper submission.

\section{Availability of data and materials}

The datasets generated and analysed during the current study are available in the institute ICAR- NBAGR, Institute Project code: 2.11 , and will be shared as and when required.

\section{Competing interests}

The authors declare no competing interests.

Funding Institute planned activity

\section{Author contributions}

KVS and RSK designed the study, KVS and RD managed resources populations and performed blood sampling, MS performed microsatellite data analysis and KVS wrote the manuscript. All authors reviewed the manuscript.

\section{Acknowledgements}

The authors wish to thank the Director, ICAR-NBAGR, Karnal, for support in carrying out the research work. The authors wish to thank the Director, Joint Directors and Veterinary Officers of Department of A.H. \& Veterinary Services, Govt. of Tripura for their active support in carrying out the field work and assistance during the collection of blood samples of buffaloes.

\section{Authors' information}


Dr Karan Veer Singh, Senior Scientist, ICAR-National Bureau of Animal Genetic Resources, Karnal, Haryana 132001 India.

Dr Ramendra Das, Veterinary Officer, Tripura Livestock Development Agency (TLDA), Animal Resources Development Department, Tripura.

Dr Monika Sodhi, Principal Scientist, ICAR-National Bureau of Animal Genetic Resources, Karnal, Haryana 132001 India.

Dr R. S Kataria Principal Scientist, ICAR-National Bureau of Animal Genetic Resources, Karnal, Haryana 132001 India.

\section{References}

1. ICAR- National Bureau of Animal Genetic Resources-http://www.nbagr.res.in, 2021.

2. Ministry of Agriculture and Farmers Welfare, Gol. 20th Livestock Census Report. New Delhi, India: Department of Animal Husbandry DAHDF.

3. Tantia, M.S., Vijh, R.K., Mishra, B., Kumar, S.T., and Arora, R. Multi locus genotyping to study population structure in three buffalo populations of India. Asian Australasian Journal of Animal Science 19(8), 1071-1078 (2006).

4. Khade, K.A., Panigrahi, M., Sheikh, F.A., Kumar, P., Bhushan, B. Genetic characterization and assessment of diversity in Pandharpuri buffalo breed of India using heterologous microsatellite markers. Animal Biotechnology 1-6, doi:10.1080/10495398, 1612757 (2019).

5. Vijh, R.K., Tantia, M.S., Mishra, B.P., and Bharani, Kumar., Genetic relationship and diversity analysis of Indian water buffalo (Bubalus bubalis). Journal of Animal Science 86(7), 1495-1502 (2008).

6. Kataria, R.S., Kathiravan, P., Bulandi, S.S., Yadav, N.K., Dubey, P.K., and Mishra, B.P. Assessment of genetic diversity, mutation drift equilibrium and Mitochondrial D-loop variation in Toda buffalo - The endangered breed of South India. Journal of Applied Animal Research 35(1), 67-72 (2009).

7. Kataria, R.S., Sunder, S., Malik, G., Mukesh, M., Kathiravan, P., and Mishra, B.P. Genetic diversity and bottleneck analysis of Nagpuri buffalo breed of India based on microsatellite data. Russian Journal of Genetics 45(7), 826-832 (2009).

8. Jakhesara, S.J., Rank, D.N., Kansara, J.D., Parikh, R.C., Vataliya, P.H., and Solanki, J.V., Microsatellite DNA typing for assessment of genetic variability in the Mehsana buffalo breed of India. Buffalo Bulletin 29(4): 262-269(2010).

9. Kannur, B.H., Fairoze, M.N., Girish, P.S., et al. Microsatellite based polymorphism and genetic diversity among Indian buffalo breeds. Indian Journal of Animal Science 87(6):731-735 (2017).

10. Singh, R., Lavakumar, S., Ankita, G., et al. STR markers based genetic diversity evaluation of Chilika buffalo of Odisha state. Journal of Livestock Biodiversity 8(1):29-35 (2018).

11. Singh, N.P., Vohra, V., Das, R., Verma, U., Tantia, M.S., and Kataria, R.S., Elucidating the genetic diversity using SSR based markers in Gojri buffalo. Indian Journal of Animal Science 89(5):522-527 (2019).

12. Angel-Marın, P.A., Cardona, H., Moreno-Ochoa, M., and Ceron-Mu noz, M., Analysis of genetic diversity in Colombian buffalo herds. Revista Colombiana de Ciencias Pecuarias 23:411-421 (2010).

13. Acosta, A., Uffo, O., Sanz, A., et al. Genetic characterization of the Cuban water buffalo population using microsatellite DNA markers. Buffalo Bulletin 33(1): 101-106 (2014).

14. Attia, M., Abou-Bakr, S., Hafez, Y.M., Genetic polymorphism of seven microsatellite DNA markers in Egyptian buffalo. Paper presented at the $2^{\text {nd }}$ International Conference on Biotechnology Applications in Agriculture (ICBAA); April 8-12, 2014; Benha, Egypt.

15. Food and Agriculture Organization (FAO) http://www.fao.org/3/i2413e/i2413e00.pdf

16. Mishra, B. P., Dubey, P. K., Prakash, B., Kathiravan, P., Goyal, S., Sadana, D. K., Das, G. C., Goswami, R. N., Bhasin, V., Joshi, B. K., \& Kataria, R. S. Genetic analysis of river, swamp and hybrid buffaloes of north-east India throw new light on phylogeography of water buffalo (Bubalus bubalis). Journal of animal breeding and genetics 132(6), 454-466 (2015).

17. Karan Veer Singh, Verma, U.K., Arora, , Kataria, R.S., and Niranjan, S. Cytogenetic analysis reveals existence of swamp buffalo population in Meghalaya. The Indian journal of animal sciences 90(6):868-870 (2020).

18. Karan Veer Singh, Ramendra Das, Lavakumar, S., Sodhi, M., and Kataria, R. S., Karyotypic and mtDNA based characterization of 'Bhangor', swamp buffalo population of Tripura Internation journal of Livestock research,Vol 11(3),149-153.

19. Navani N, Jain PK, Gupta S, Sisodia BS, Kumar S. A set of cattle microsatellite DNA markers for genome analysis of riverine buffalo (Bubalus bubalis). Animal Genetics. 2002;33(2):149-154.

20. Kumar S, Gupta J, Kumar N, Dikshit K, Navani N, Jain P, Nagarajan M: Genetic variation and relationships among eight Indian riverine buffalo breeds. Mol Ecol. 2006, 15: 593-600.

21. Arora, R., Lakhchaura, B.D., Prasad, R.B., Tantia, M.S., and Vijh, R.K. Genetic diversity analysis of two buffalo populations of northern India using microsatellite markers. J Anim Breed Genet. 121 (2):111-118 (2004). 
22. Aminafshar, M., Airinia, C and Torshizi, R.V. 2008. Genetic diversity in Buffalo Population of Gullian using Microsatellite markers. Buffalo Bull., 7(11): 1499-1502.

23. Ghosh, S., Majumder, M., and Barman, R. N. Wetlands of Tripura, Identification of Ecological Sensitivity: Volume 1, (1997).

24. http://kiran.nic.in/nrcp/tripura/Research_Higlights/Introduction_of_Murrah_Buffalo_Sahiwal_Cattle.pdf

25. Mishra, B.P., Kataria, R.S., Kathiravan, P., Sadana, D.K., Microsatellite based genetic characterization of Jaffarabadi buffaloes. Indian Veterinary Journal 86(4): 376-379 (2009).

26. Mishra, B.P., Kataria, R.S., Kathiravan, P., Bulandi, S.S., Singh, K.P, and Sadana, D.K., Evaluation of genetic variability and mutation drift equilibrium of Banni buffalo using multi locus microsatellite markers. Tropical Animal Health and Production 41(7):1203 (2009).

27. Sukla, S., Yadav, B.R., and Bhattacharya, T.K., Characterization of Indian riverine buffaloes by microsatellite markers. Asian Australasian Journal of Animal Science 19(11):1556-1560 (2006).

28. Ozkan Unal, E., Soysal, M.I., Yuncu, E., Dagtas, N.D., and Togan, I. Microsatellite based genetic diversity among the three water buffalo (Bubalus bubalis) populations in Turkey. Arch Anim Breed. 57(1):1-12 (2014).

29. Botstein, D., White, R.L., Skolnick, M., Davis, R.W., Construction of genetic linkage maps in man using restriction fragment length polymorphisms. American Journal of Human Genetics 32:314-331(1980).

30. Kataria RS, Sunder S, Malik G, Mukesh M, Kathiravan P, Mishra BP. Genetic diversity and bottleneck analysis of Nagpuri buffalo breed of India based on microsatellite data. Russ J Genet. 2009;45(7):826-832.

31. Kathiravan, P., Mishra, B.P., Kataria, R.S., and Sadana, D.K., Evaluation of genetic architecture and mutation drift equilibrium of Marathwada buffalo population in Central India. Livestock Science. 121(2-3): 288-293 (2009).

32. Attia, S., Abou-Bakr and A.A.Nigm Genetic differentiation and relationship among egyptian nile delta located buffalo using microsatellite markers. Egyptian J. Anim. Prod. (2014) 51(2):71-77.

33. Sambrook, J., Russell, D.W., Molecular Cloning: A Laboratory Manual. 3rd ed. Cold Spring Harbor, NY: Cold Spring Laboratory Press 561590 (2001).

34. GeneMapper Software, Applied Biosystem

35. Peakall, R., Smouse, P.E., GenAIEx 6.5: genetic analysis in Excel. Population genetic software for teaching and research - an update. Bioinformatics 28(19): 2537-2539 (2012).

36. Goudet, J., FSTAT [computer software], a program to estimate and test gene diversities and fixation indices. Version 2.9.3. Lausanne, Switzerland: Lausanne University; 2001.

37. Piry, S., Luikart, G., and Cornuet, J-M., Bottleneck: a computer program for detecting recent reduction in the effective population size using allele frequency data. Journal of Heredity 90(4):502-503 (1999).

\section{Tables}

Table no 1. Details of heterologous bovine microsatellite markers used to study genetic diversity in Bhangor buffalo population. 


\begin{tabular}{|c|c|c|c|}
\hline Loci & Primer sequence $\left(5^{\prime}-3^{\prime}\right)$ & Chromosome & Annealing Temperature \\
\hline CSSM33 & $\begin{array}{l}\text { F-CACTGTGAATGCATGTGTGTGAGC } \\
\text { R-CCCATGATAAGAGTGCAGATGACT }\end{array}$ & $17(17)$ & 65 \\
\hline BM1818 & $\begin{array}{l}\text { F-AGCTGGGAATATAACCAAAGG } \\
\text { R-AGTGCTTTCAAGGTCCATGC }\end{array}$ & $23(2 p)$ & 58 \\
\hline CSRM60 & $\begin{array}{l}\text { F-AAGATGTGATCCAAGAGAGAGGCA } \\
\text { R-AGGACCAGATCGTGAAAGGCATAG }\end{array}$ & $10(11)$ & 55 \\
\hline HEL13 & $\begin{array}{l}\text { F- TAAGGACTTGAGATAAGGAG } \\
\text { R- CCATCTACCTCCATCTTAAC }\end{array}$ & 11 & 52 \\
\hline ILSTS019 & $\begin{array}{l}\text { F-AAGGGACCTCATGTAGAAGC } \\
\text { R-ACTTTTGGACCCTGTAGTGC }\end{array}$ & $29(5 p)$ & 55 \\
\hline ILSTS025 & $\begin{array}{l}\text { F-GTTACCTTTATATAAGACTCCC } \\
\text { R-AATTTCTGGCTGACTTGGACC }\end{array}$ & 2 & 55 \\
\hline ILSTS028 & $\begin{array}{l}\text { F-TCCAGATTTTGTACCAGACC } \\
\text { R-GTCATGTCATACCTTTGAGC }\end{array}$ & 11 & 55 \\
\hline ILSTS029 & $\begin{array}{l}\text { F-TGTTTTGATGGAACACAGCC } \\
\text { R-TGGATTTAGACCAGGGTTGG }\end{array}$ & $3(6)$ & 55 \\
\hline ILSTS030 & $\begin{array}{l}\text { F-CTGCAGTTCTGCATATGTGG } \\
\text { R-CTTAGACAACAGGGGTTTGG }\end{array}$ & $2(2 q)$ & 55 \\
\hline ILSTS033 & $\begin{array}{l}\text { F-TATTAGAGTGGCTCAGTGCC } \\
\text { R-ATGCAGACAGTTTTAGAGGG }\end{array}$ & $12(13)$ & 55 \\
\hline ILSTS036 & $\begin{array}{l}\text { F-GAGTATTATGCTTGGGAGGC } \\
\text { R-AGACAGGATGGGAAGTCACC }\end{array}$ & 11 & 55 \\
\hline ILSTS056 & $\begin{array}{l}\text { F-GCTACTGAGTGATGGTAGGG } \\
\text { R-AATATAGCCCTGGAGGATGG }\end{array}$ & & 55 \\
\hline ILSTS058 & $\begin{array}{l}\text { F-GCCTTACTACCATTTCCAGC } \\
\text { R-CATCCTGACTTTGGCTGTGG }\end{array}$ & 17 & 55 \\
\hline ILSTS061 & $\begin{array}{l}\text { F-AAATTATAGGGGCCATACGG } \\
\text { R-TGGCCTACCCTACCATTTCC }\end{array}$ & 15 & 55 \\
\hline ILSTS089 & $\begin{array}{l}\text { F-AATTCCGTGGACTGAGGAGC } \\
\text { R-AAGGAACTTTCAACCTGAGG }\end{array}$ & $29(5 p)$ & 55 \\
\hline ETH003 & $\begin{array}{l}\text { F-GAACCTGCCTCTCCTGCATTGG } \\
\text { R-ACTCTGCCTGTGGCCAAGTAGG }\end{array}$ & $19(3 p)$ & 58 \\
\hline
\end{tabular}

Table no 2. Markers wise allelic diversity in Bhangor buffalo population. 


\begin{tabular}{|c|c|c|c|c|c|c|c|c|c|}
\hline Locus & $\begin{array}{l}\text { Observed } \\
\text { number } \\
\text { of alleles } \\
\mathrm{Na}\end{array}$ & $\begin{array}{l}\text { Effective } \\
\text { number } \\
\text { of } \\
\text { alleles } \\
\mathrm{Ne}\end{array}$ & $\begin{array}{l}\text { Shannon's } \\
\text { Information } \\
\text { Index } \\
I\end{array}$ & $\begin{array}{l}\text { Observed } \\
\text { heterozygosity } \\
H_{O}\end{array}$ & $\begin{array}{l}\text { Expected } \\
\text { heterozygosity } \\
H_{e}\end{array}$ & $\begin{array}{l}\text { Allele } \\
\text { size } \\
\text { (bp) }\end{array}$ & $\begin{array}{l}\text { Nei expected } \\
\text { heterozygosity } \\
H_{e}\end{array}$ & $\begin{array}{l}\text { PIC } \\
\text { value }\end{array}$ & $\begin{array}{l}\text { Coefficient } \\
\text { of } \\
\text { inbreeding } \\
F_{\text {is }}\end{array}$ \\
\hline CSSM33 & 8 & 4.340 & 1.715 & 0.840 & 0.770 & $\begin{array}{l}157- \\
179\end{array}$ & 0.785 & 0.740 & -0.0915 \\
\hline BM1818 & 9 & 4.614 & 1.742 & 0.850 & 0.784 & $\begin{array}{l}244- \\
300\end{array}$ & 0.804 & 0.776 & -0.0845 \\
\hline CSRM60 & 3 & 1.865 & 0.725 & 0.091 & 0.464 & $\begin{array}{l}92- \\
132\end{array}$ & 0.475 & 0.432 & 0.8040 \\
\hline HEL13 & 9 & 3.070 & 1.412 & 0.968 & 0.674 & $\begin{array}{l}174- \\
200\end{array}$ & 0.685 & 0.627 & -0.4352 \\
\hline ILSTS019 & 6 & 2.207 & 1.093 & 0.129 & 0.547 & $\begin{array}{l}175- \\
182\end{array}$ & 0.556 & 0.538 & 0.7640 \\
\hline ILSTS025 & 3 & 1.072 & 0.174 & 0.069 & 0.067 & $\begin{array}{l}113- \\
144\end{array}$ & 0.068 & 0.03 & -0.0265 \\
\hline ILSTS028 & 10 & 5.095 & 1.831 & 0.656 & 0.804 & $\begin{array}{l}143- \\
175\end{array}$ & 0.816 & 0.750 & 0.1835 \\
\hline ILSTS029 & 8 & 2.379 & 1.332 & 0.677 & 0.580 & $\begin{array}{l}156- \\
170\end{array}$ & 0.589 & 0.545 & -0.1688 \\
\hline ILSTS033 & 6 & 3.165 & 1.404 & 0.560 & 0.684 & $\begin{array}{l}140- \\
152\end{array}$ & 0.698 & 0.629 & 0.1813 \\
\hline ILSTS036 & 6 & 3.189 & 1.370 & 0.615 & 0.686 & $\begin{array}{l}124- \\
172\end{array}$ & 0.700 & 0.646 & 0.1034 \\
\hline ILSTS056 & 12 & 5.143 & 2.020 & 0.500 & 0.823 & $\begin{array}{l}144- \\
182\end{array}$ & 0.823 & 0.785 & 0.3793 \\
\hline ILSTS058 & 8 & 6.672 & 1.958 & 0.714 & 0.850 & $\begin{array}{l}130- \\
144\end{array}$ & 0.866 & 0.848 & 0.1598 \\
\hline ILSTS061 & 12 & 5.523 & 2.054 & 0.774 & 0.819 & $\begin{array}{l}137- \\
161\end{array}$ & 0.832 & 0.802 & 0.0546 \\
\hline ILSTS089 & 7 & 4.133 & 1.604 & 0.391 & 0.758 & $\begin{array}{l}114- \\
128\end{array}$ & 0.775 & 0.697 & 0.4838 \\
\hline ETH003 & 7 & 4.056 & 1.652 & 0.167 & 0.753 & $\begin{array}{l}109- \\
133\end{array}$ & 0.786 & 0.741 & 0.7788 \\
\hline Mean & 7.600 & 3.769 & 1.472 & 0.533 & 0.670 & & 0.684 & & 0.114 \\
\hline SE & 0.689 & 0.396 & 0.131 & 0.077 & 0.052 & & 0.053 & & 0.033 \\
\hline
\end{tabular}

Table no 3. Mutations drift equilibrium, heterozygosity excess/deficiency under different mutation models in Bhangor buffalo population. 


\begin{tabular}{|c|c|c|c|}
\hline Test & Parameters & IAM & SMM \\
\hline \multirow[t]{4}{*}{ Sign Test } & Observed no. of loci with $\mathrm{H}_{\mathrm{e}}$ excess & 16 & 2 \\
\hline & Expected no. of loci with $\mathrm{H}_{\mathrm{e}}$ excess & 14.15 & 14.22 \\
\hline & \multirow{2}{*}{$\begin{array}{l}\text { Loci with heterozygosity deficiency } \\
p \text {-value }\end{array}$} & 8 & 22 \\
\hline & & 0.2911 & 0.000 \\
\hline \multirow[t]{2}{*}{ Standardized difference test } & \multirow{2}{*}{$\begin{array}{l}\text { T2 value } \\
p \text {-value }\end{array}$} & 0.562 & -8.835 \\
\hline & & 0.287 & 0.287 \\
\hline \multirow[t]{3}{*}{ Wilcoxon sign rank test } & \multirow{3}{*}{$\begin{array}{l}p \text { (one tail for } \mathrm{H} \text { deficiency) } \\
p \text {-value (one tail for } \mathrm{H} \text { excess) } \\
p \text {-value (two tail test for } \mathrm{H}_{\mathrm{e}} \text { excess or deficiency) }\end{array}$} & 0.855 & 0.000 \\
\hline & & 0.151 & 1.000 \\
\hline & & 0.302 & 0.00001 \\
\hline
\end{tabular}

Estimation based on 1000 replications; He: heterozygosity excess expected; p: probability; IAM: infinite allele model; SMM: step-wise mutation model.

Table no 4. Pairwise Population $F_{s t}$ values and pairwise gene flow $N_{m}$ (above diagonal)

\begin{tabular}{llllllll}
\hline Population & Bhangor & Murrah & Manda & Chilika & Kalahandi & Manipur & Assam \\
\hline Bhangor & 0 & 0.689 & 0.21 & 0.161 & 0.255 & 1.127 & 1.568 \\
Murrah & 0.21 & 0 & 1.861 & 0.958 & 1.089 & 1.142 & 2.174 \\
Manda & 0.143 & 0.21 & 0 & 1.003 & 1.045 & 2.192 & 1.8 \\
Chilika & 0.149 & 0.143 & 0.093 & 0 & 0.255 & 0.145 & 0.154 \\
Kalahandi & 0.146 & 0.149 & 0.12 & 0.04 & 0 & 1.346 & 1.446 \\
Manipur & 0.083 & 0.157 & 0.157 & 0.146 & 0.139 & 0 & 0.148 \\
Assam & 0.097 & 0.152 & 0.198 & 0.136 & 0.117 & 0.124 & 0 \\
\hline
\end{tabular}

\section{Figures}




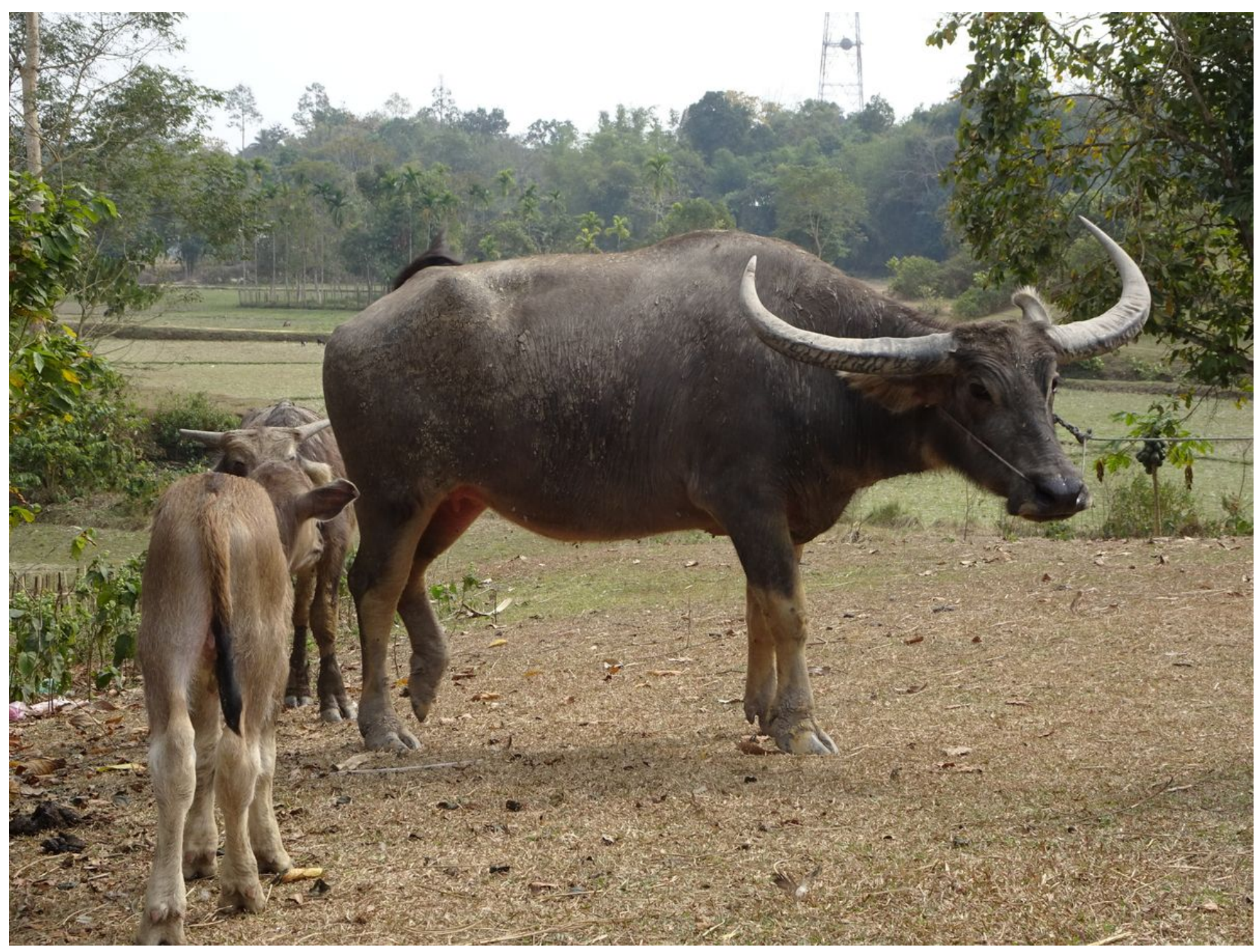

\section{Figure 1}

Adult female Bhangor buffalo (location Kamalpur, Tripura) 


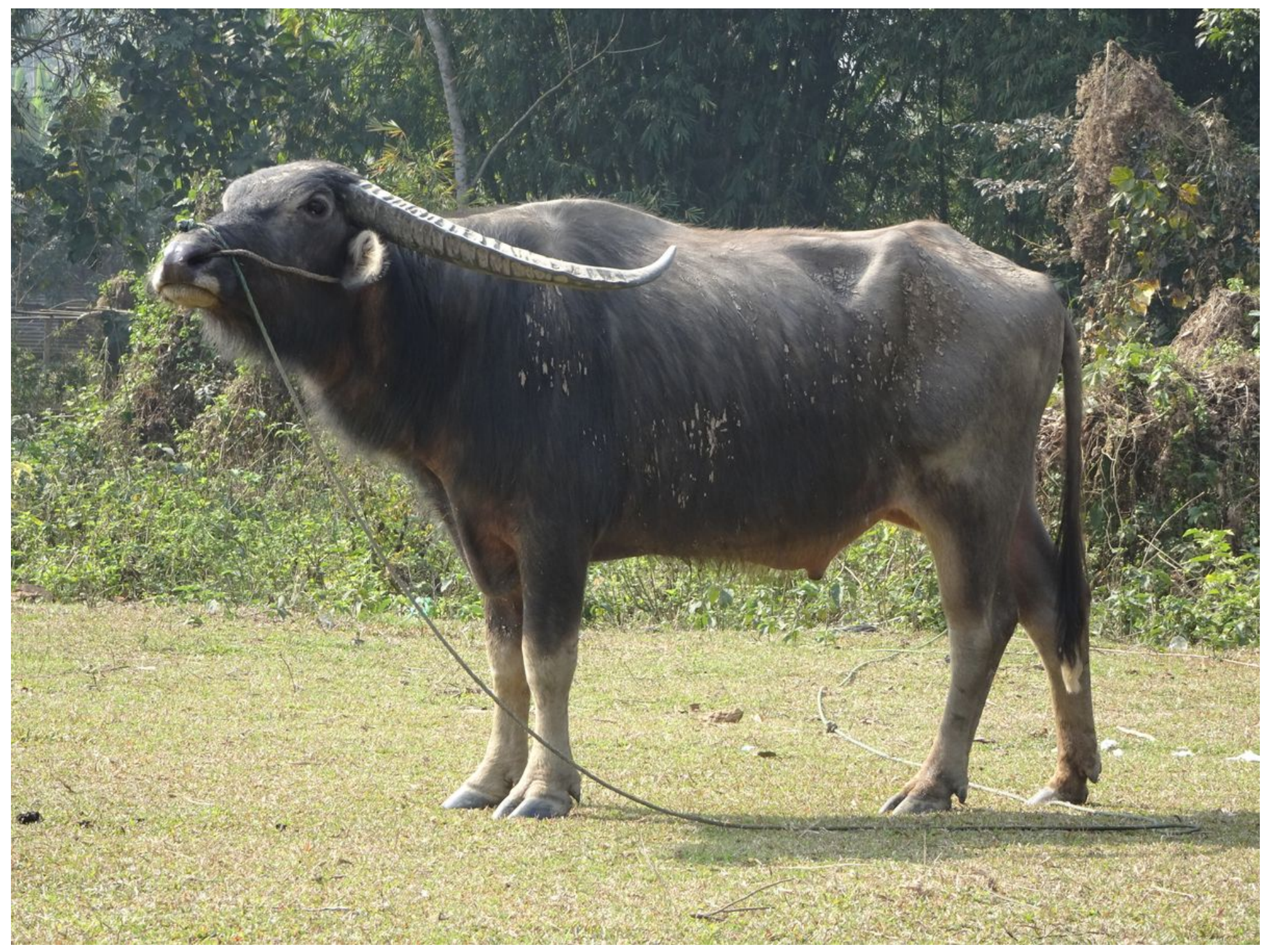

Figure 2

Adult male Bhangor buffalo pair (location Kamalpur, Tripura).JPG

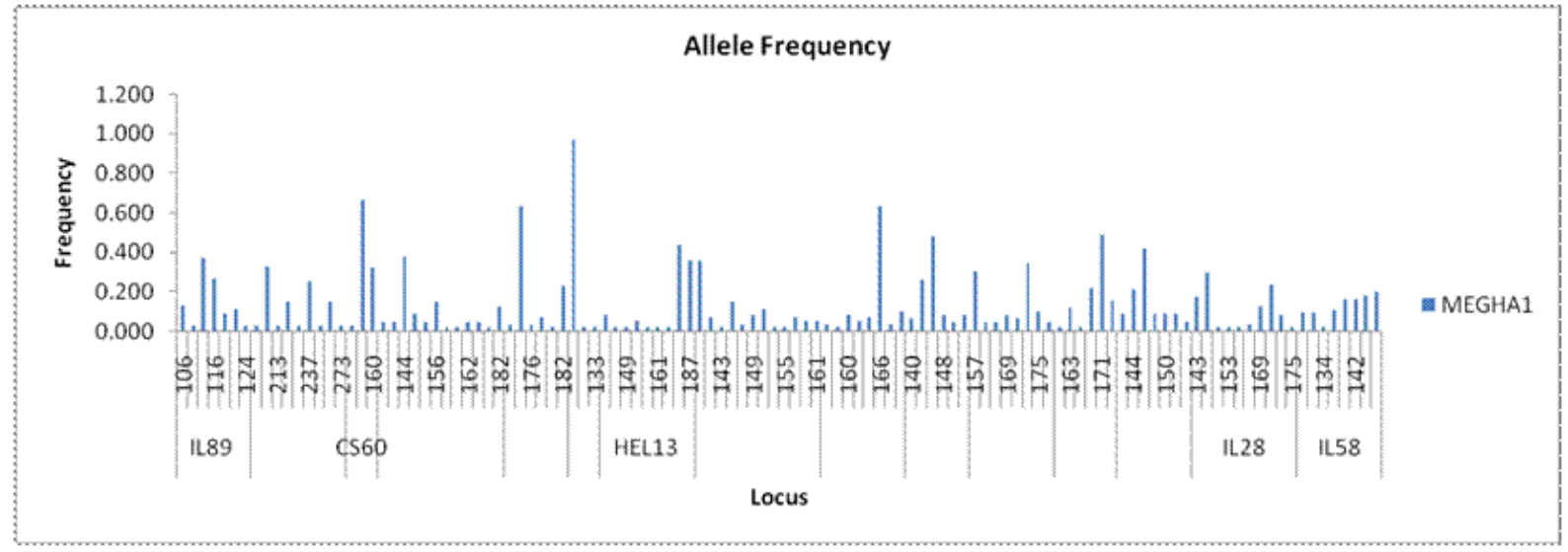

\section{Figure 3}

Lucus wise allele frquency distribution in Bhangor buffalo.gif 


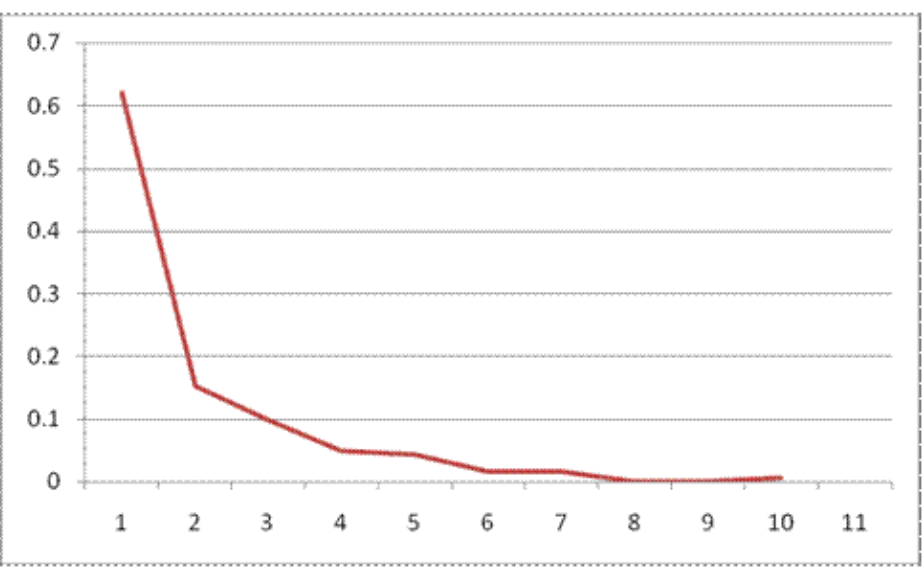

Figure 4

L-Shaped mode-shift graph showing lack of bottleneck in Bhangor buffalo population

\section{Supplementary Files}

This is a list of supplementary files associated with this preprint. Click to download.

- equations.docx 